\title{
A18 実投球された野球ボールの軌道と縫い目位固の影響 The trajectories of the actually pitched baseball with different seam-positions
}

\author{
○学山田啓輔（九工大・院）富成亮介（九工大・学) \\ 正平木 講儒 (九工大・工) 正 井上 昌信 (九工大・工)
}

Keisuke YAMADA, Kyushu Institute of Technology, Sensuicho1-1, Tobata-ku, Kitakyushu-shi Ryosuke TOMINARI, Kyushu Institute of Technology

Koju HIRAKI, Kyushu Institute of Technology

Masanobu INOUE, Kyushu Institute of Technology

\begin{abstract}
A gyroball was actually pitched to investigate the influence of seam-positions. The differences due to the lift force were found in the trajectories of gyroball and fastball obtained by the high-speed video cameras. The gyroball dropped $20 \mathrm{~cm}$ deeper than the fastball. However it was unable to distinguish the influence of seam-positions of gyroball in the trajectories. The drag coefficient can be estimated from the initial and final velocities of the pitched baseball which were obtained by the high-speed video cameras. The drag coefficients of the gyroballs were smaller than that of the fastballs. Furthermore, the drag coefficient for the 2 seam-position was smaller than that for the $4 \mathrm{seam}$-position.
\end{abstract}

Key Words: Gyroball, Seam-positions, Trajectory, Drag coefficient

\section{1. 序論}

現在, 野球の変化球の中で「ジャイロボール」という球 種が注目を集めている。 ジャイロボールとは, 進行方向と 回転軸が一致（ライフル回転）するように投じられるため 揚力が働かず, 縦に落ちるように変化する. また, 抗力係 数も他の球種と比べ小さいとされているため, 打者の予測 した到達時間より速く到達するとされている。 1) 6)

ジャイロボールに関する研究は近年盛んに行われており, ジャイロボールの縫い目の位置による空力特性の相違も研 究されている. 主に研究されているジャイロボールの縫い 目位置は, Fig.1に示すようにボールが 1 回転する間に 2 回 縫い目が現れる 2 シームと, 4 回現れる 4 シームがある. 姫野は数值計算により, 抗力係数が 2 シームでは $0.29,4$ シームでは 0.17 と他の球種より小さいことを示した ${ }^{2)}$. 溝 田らは径の小さいピアノ線を用いてボールを支持した風洞 実験を行い, 抗力係数が 2 シームでは $0.28,4$ シームでは 0.35 という結果を示した ${ }^{3)}$. 姫野の数值計算結果では, 4 シームが 2 シームより抗力係数が小さくなっているが, 溝 田らの風洞実験結果では，その逆となっている，また， 4 シームの抗力係数にいたっては, 姫野と溝田らの結果に 2 倍の差がある. そのため, ジャイロボールの縫い目位置の 効果に関しては，まだ少なからず研究の余地がある。

そこで本稿では, ジャイロボールの縫い目位置による空 力特性の相違を確かめるために, 実投球された 2 シームと 4 シームのジャイロボールをハイスピードビデオカメラに より撮影し, 軌道及び初速と終速の差の観点より評価した. 比較のためにジャイロボールと同じ鈶直面内で変化するス トレート，フォークも実験の対象とした。

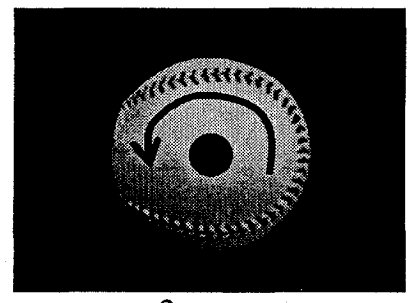

2seam

Fig.1. Typical seam-positions

\section{2. ジャイロ回転}

Fig.2 に筆者の投じたジャイロボールの回転の様子を示 す．縫い目の位置は 2 シームである，撮影は，ピッチャー の後方から毎秒 240 フレームで行った. 1〜8（0.033[s]）で ボールがほぼ 1 回転しており, ボールに付けられているマ 一クが常に中心に位置し, 回転の軸が進行方向と一致して いることが分かる.

今回の実験では，このような回転が得られた投球のみジ ヤイロボールとして実験結果の評価をしている.

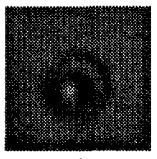

1

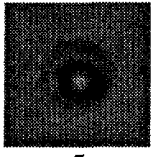

5

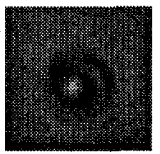

2

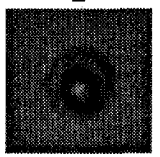

6

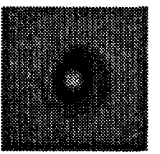

3

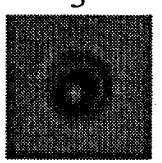

7
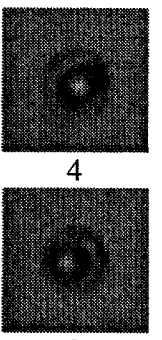

8
Fig.2 Rotation of actually pitched gyroball

\section{3. 軌道による評価}

ジャイロボールは，揚力が働かず，縫い目位置の違いで 抗力係数が異なるとされている 2),3). そのためジャイロボ 一ルの軌道は， 2 シームと 4 シームで抗力係数の差により 異なると考元られる。そこでハイスピードビデオカメラで 軌道を撮影し，絡い目位置の影響を評価した。

\section{3-1. 軌道の測定方法}

実験装置の配置図を Fig.3 に示す.実験場所の都合によ り, 軌道の撮影距離は, キャッチャー側から $13 \mathrm{~m}$ とした. ボールの軌道亡回転を同時に撮影するため, 2 台の八イス ピードビデオカメラを使用した。軌道の撮影には, ノビテ ック社製 Phantom（毎秒 300 フレーム），回転の撮影には,

日本機械学会 [No.07-24] シンポジウム講演論文集

[07-11-14〜16,つくば市,ジョイント・シンボジウム2007（スポーツエ学シンポジウム）(シンポジウム：ヒューマン・ダイナミクス)] 
フォトロン社製 FASTCAM-Rabbit-mini(毎秒 240 フレーム) を用いた．回転を同時に撮影することで，ボールの回転軸 と回転数を読み取り，軌道の評価の参考にした．撮影した 軌道の映像から動画解析ソフト（VideoPoint2.5）を用いて 軌道を解析した。

\section{3-2. 軌道の測定結果}

ほぼ同じ球速と投射角度で投じられたジャイロボール， ストレート, フォークの初速と回転数を Table1に, 軌道を Fig.4 に示す.

Fig.4より, ジャイロボールがストレートとフォークに比 ベ, より大きく落ちていることが分かった. ジャイロボー ルがより大きく落ちる要因は，ストレートとここでのフォ 一クは揚力が㗢くような回転をしているためであると考え られる.また, この実験の条件では, ジャイロボールとス トレートの落差の差は約 $20[\mathrm{~cm}]$ あることが分かった.

次に, Fig.5に示すように 2 シームジャイロと 4 シームジ ヤイロのみの軌道を比較した．この 2 つの軌道は，きれい にジャイロ回転しており, 投射角, 初速共にかなり近いも のを比較したが, 2 シームと 4 シームによる縫い目位置の 違いによる軌道への影響はほぼ見られなかった。ジャイロ ボールは縫い目位置の違いで抗力係数が違うとされている ため，その抗力係数の違いにより， 2 シームと 4 シームで 軌道に差が生じると予測していたが，抗力係数の違いによ る軌道への影響はほとんどないと考えられる。

Table1 Velocity and number of revolution

\begin{tabular}{cccc}
\hline & \multicolumn{2}{c}{ Velocity $[\mathrm{km} / \mathrm{h}]$} & Number of revolution \\
& Initial & Final & [rps] \\
\hline 2seam-Gyro & 98 & 91 & 36 \\
4seam-Gyro & 96 & 87 & 31 \\
Fastball & 98 & 90 & 24 \\
Forkball & 97 & 87 & 11 \\
\hline
\end{tabular}

3-3. シミュレーションによる軌道

\section{3-3-1. 運動方程式 7)}

飛翔中の野球ボールに働く力は, 大別して重力と空気力 があり, 空気力は抗力, 揚力, 横力に分けられる. Fig.6の ように軸を定義すると,これらの空気力は式（1）のように 表され,また, 野球ボールの運動方程式は式（2）のように 表される。

$$
\begin{aligned}
& \left\{\begin{array}{l}
\mathbf{D}=-\frac{1}{2} \rho C_{D} A V \mathbf{V} \\
\mathbf{L}=-\frac{1}{2} \rho C_{L} \sin \gamma A V^{2} \frac{\omega \times \mathbf{V}}{|\omega \times \mathbf{V}|} \\
\mathbf{Y}=-\frac{1}{2} \rho C_{Y} \sin \gamma A V^{2} \frac{\mathbf{L} \times \mathbf{D}}{|\mathbf{L} \times \mathbf{D}|}
\end{array}\right. \\
& \left\{\begin{array}{l}
m \frac{d^{2} x}{d t}=D_{x}+L_{x}+Y_{x} \\
m \frac{d^{2} y}{d t}=D_{y}+L_{y}+Y_{y} \\
m \frac{d^{2} x}{d t}=D_{z}+L_{z}+Y_{z}-g
\end{array}\right.
\end{aligned}
$$

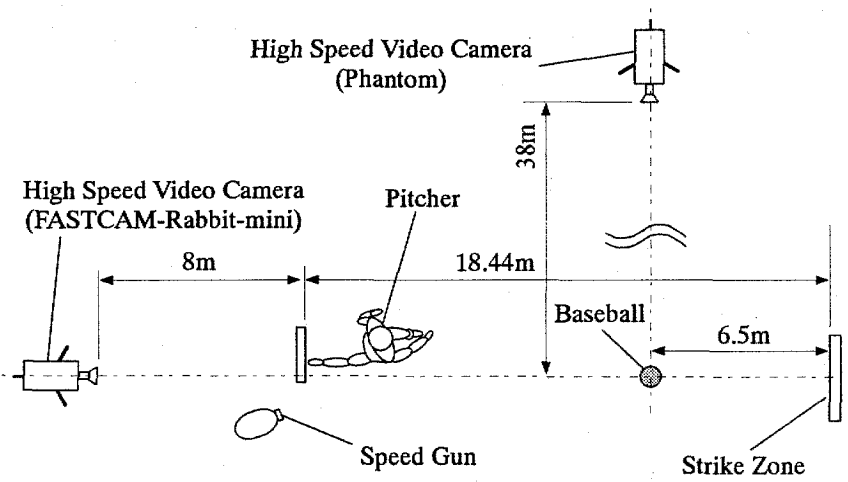

Fig.3 Location of experimental equipments (Trajectory)

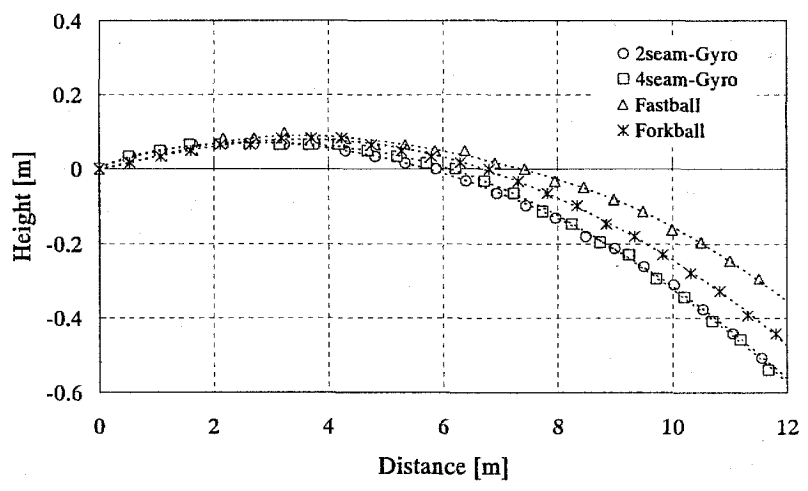

Fig.4 Comparison of trajectories

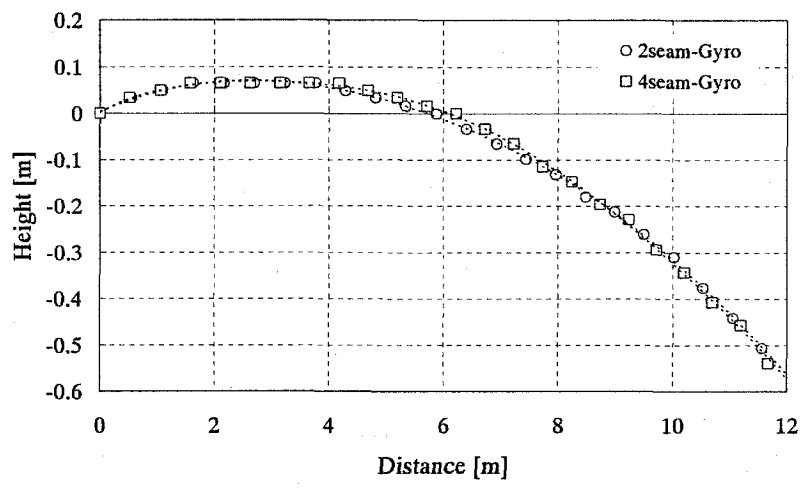

Fig.5 Comparison of trajectories（Gyroball）

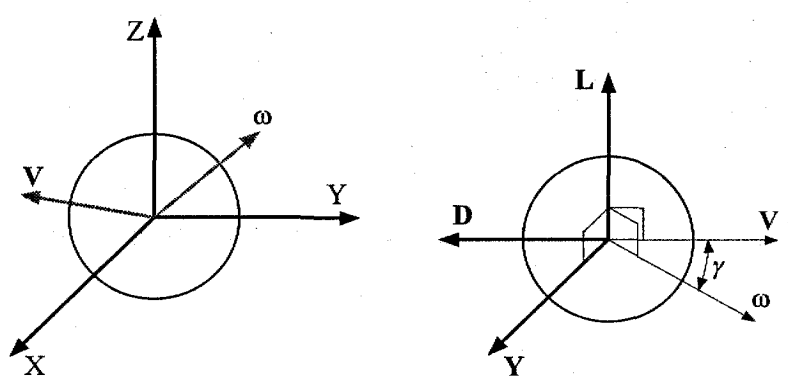

Fig.6 Definition of axis ${ }^{7)}$ 
ここで, $D$ は抗力 $[\mathrm{N}], C_{D}$ は抗力係数, $L$ は揚力 $[\mathrm{N}], C_{L}$ は揚力係数, $Y$ は横力 $[\mathrm{N}], C_{Y}$ は横力係数, $\rho$ は空気密度 $\left[\mathrm{kg} / \mathrm{m}^{3}\right], A$ はボールの投影面積 $\left[\mathrm{m}^{2}\right], V$ はボールの速度 $[\mathrm{m} / \mathrm{s}]$,

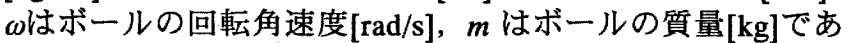
る.

式（1）と式（2）を展開すると,

$\left\{\begin{array}{c}\dot{V}_{x}=\frac{\rho A V}{2 m}\left[\begin{array}{c}\frac{C_{L}}{\omega}\left(V_{z} \omega_{y}-\omega_{z} V_{y}\right)-C_{D} V_{x} \\ +\frac{C_{Y}}{\omega V}\left(V_{y}^{2} \omega_{x}-V_{x} V_{y} \omega_{y}-V_{x} V_{z} \omega_{z}+V_{z}^{2} \omega_{x}\right)\end{array}\right] \\ \dot{V}_{y}=\frac{\rho A V}{2 m}\left[\begin{array}{c}\frac{C_{L}}{\omega}\left(V_{x} \omega_{z}-\omega_{x} V_{z}\right)-C_{D} V_{y} \\ +\frac{C_{Y}}{\omega V}\left(V_{z}^{2} \omega_{y}-V_{y} V_{z} \omega_{z}-V_{y} V_{x} \omega_{x}+V_{x}^{2} \omega_{y}\right)\end{array}\right] \\ \dot{V}_{z}=\frac{\rho A V}{2 m}\left[\begin{array}{c}\frac{C_{L}}{\omega}\left(V_{y} \omega_{x}-\omega_{y} V_{x}\right)-C_{D} V_{z} \\ +\frac{C_{Y}}{\omega V}\left(V_{x}^{2} \omega_{z}-V_{z} V_{x} \omega_{x}-V_{z} V_{y} \omega_{y}+V_{y}^{2} \omega_{x}\right)\end{array}\right]-g\end{array}\right.$

となる. 式（3）をルンゲクッタ法を用いて数值積分し，軌 道を求める。

\section{3-3-2. 計算結果}

Fig.7に2 シームと 4 シームのジャイロボールの軌道と速 度の計算結果を示す。このとき, $C_{D}$ は風洞実験で得られた 0.28 (2 シーム) $0.35(4 \text { シーム })^{3)}, C_{L}$ は $0, C_{Y}$ は 0 , 初 速は $100[\mathrm{~km} / \mathrm{h}]$, 回転数は $30[\mathrm{rps}]$ として計算した.

Fig.7より，ボールが投じられて $12[\mathrm{~m}]$ の位置では，2 シ 一ムと 4 シームの軌道の差は, 僅か $1[\mathrm{~cm}]$ 程度しかないこ とが分かった.これは, Fig.5 で示した実投球の結果で軌道 の差が見られなかったこととほほ一致する。このため, ジ ヤイロボールの縫い目位置の影響を軌道で評価することは 難しい. しかし， 2 シームと 4 シームの終速の差は約 $1.5[\mathrm{~km} / \mathrm{h}]$ あり，この差を測定することはできるのではない かと考えた。

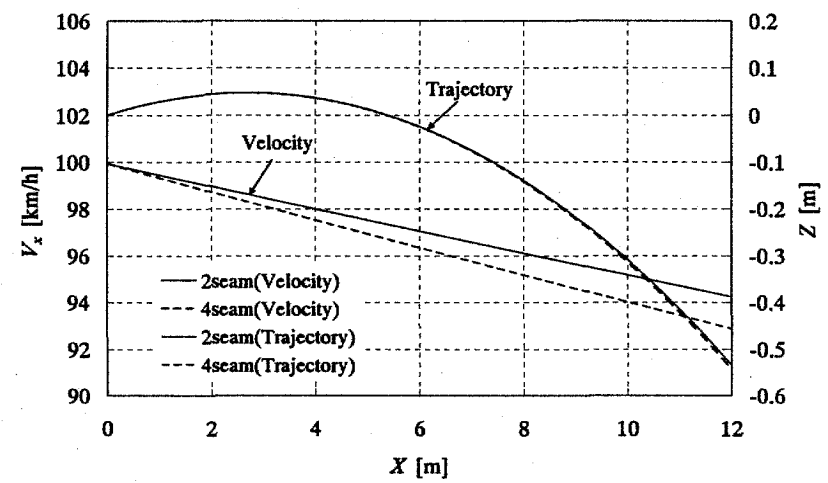

Fig.7 Simulated trajectories and velocities of gyroball

\section{4. 初速と䊏速の差による評価}

ジャイロボールの縫い目位置の影響を, 初速, 終速, 到 達時間をハイスピードビデオカメラより撮影し，それらの 関係から抗力係数を算出し評価した.

\section{4-1. 初速, 䊏速, 到達時間の测定方法}

実験装置の配置図を Fig.8 に示す。初速の測定にはノビ テック社製 Phantom (毎秒 400 フレーム), 終速の測定には フォトロン社製 FASTCAM-Rabbit-mini(毎秒 400 フレーム), 回転の様子とボールの飛翔時間の測定には，ナック社製 HSV-400（毎秒 200 フレーム）を用いた．参考のために, スピードガンで球速を測定した。

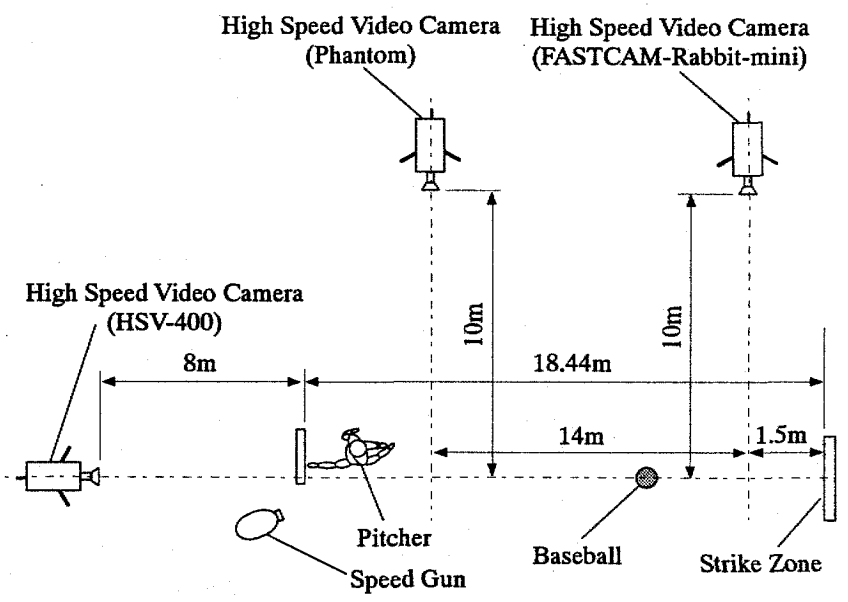

Fig.8 Location of experimental equipments $\left(C_{D}\right)$

初速と終速の算出のために，2 台のハイスピードビデオ カメラ (Phantom : 初速測定と FASTCAM-Rabbit-mini : 終 速測定）の横方向距離のフルスケールを $3[\mathrm{~m}]$ になるように 較正した. Fig.9に示すように, ボールがカメラにフレーム インした值後の距離と時間を $x_{1}, t_{1}$ とし, フレームアウト する直前の距離と時間を $x_{2}, t_{2}$ とすると, 初速 $V_{x i}$ と終速 V

$$
\begin{aligned}
& V_{x i}=\left[\frac{x_{2}-x_{1}}{t_{2}-t_{1}}\right] \text { (ピッチャーサイドのカメラ画像) } \\
& V_{x f}=\left[\frac{x_{2}-x_{1}}{t_{2}-t_{1}}\right] \text { (キャッチャーサイドのカメラ画像) }
\end{aligned}
$$

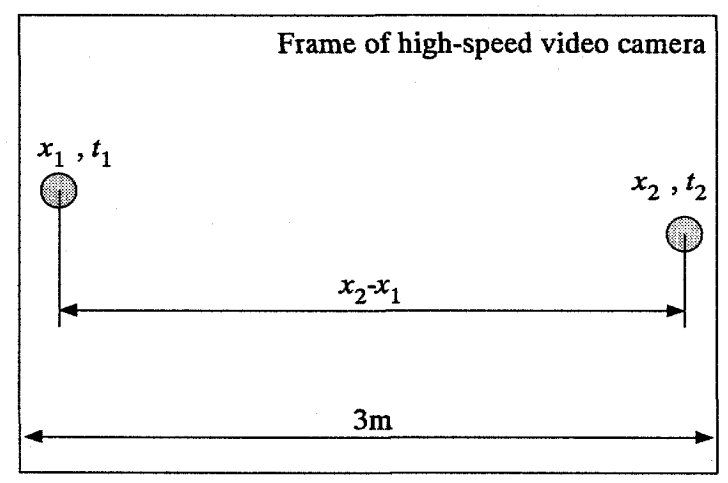

Fig.9 Measurement of velocity 
しかし，Fig.10の（b）（c）に示すような軌道の場合，八 イスピードビデオカメラの横方向距離のフルスケールが較 正值の $3[\mathrm{~m}]$ ではなくなるため, 速度を正確に測定できてい ない. そこで, Fig.11 に示すようにハイスピードビデオカ メラの視野と奥行きの関係を求め, 式（6），(7) に表され るような方法（Fig.12 参照, $a_{1}$ と $a_{2}$ はカメラに近い方を正 とする）で，より正確な速度を求めた。ここで， $V_{x i}{ }^{\prime}$ は補正 後の初速 $[\mathrm{m} / \mathrm{s}], V_{x f}$ 'は補正後の終速 $[\mathrm{m} / \mathrm{s}]$ である.

ボールの奥行き方向のずれの測定は, ピッチャー後方に 設置してあるハイスピードビデオカメラ（HSV-400）で行 った.

$$
\begin{aligned}
& V_{x i}^{\prime}=V_{x i}\left[3.0-\frac{0.1}{0.3}\left(a_{1}-\frac{a_{1}-a_{2}}{b} \frac{l}{2}\right)\right] \\
& V_{x f}^{\prime}=V_{x f}\left[3.0-\frac{0.1}{0.3}\left(a_{2}-\frac{a_{2}-a_{1}}{b} \frac{l}{2}\right)\right]
\end{aligned}
$$

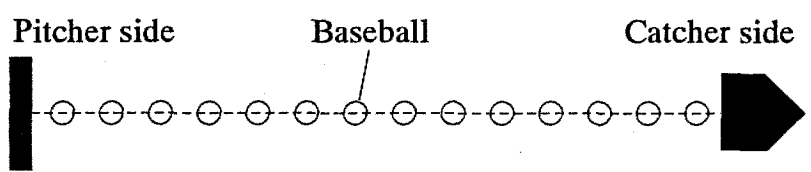

(a) $\mathrm{O}$

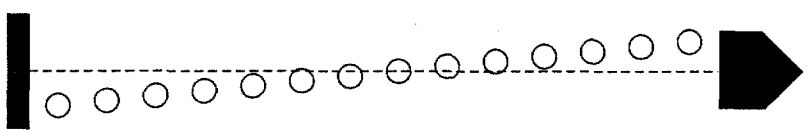

(b) $\times$

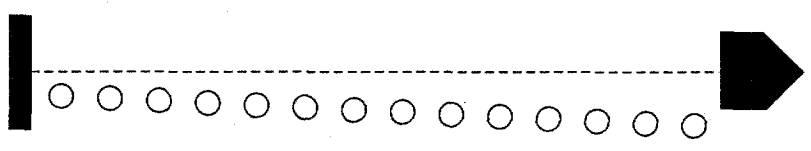

(c) $\times$

Fig.10 Trajectory of pitched baseball

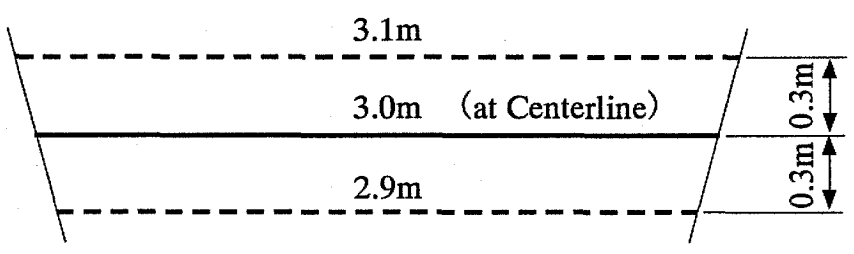

Fig.11 Calibrated length by the depth variation in camera image

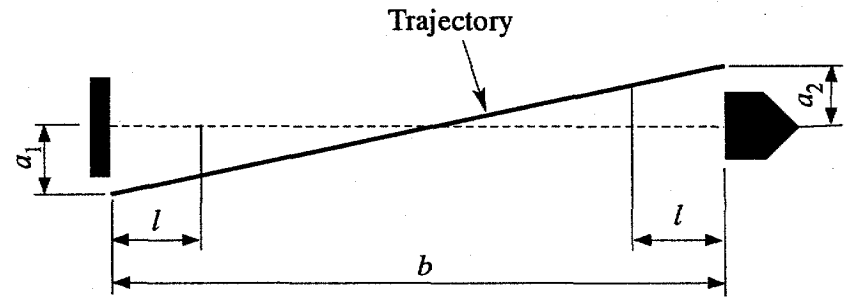

Fig.12 Correction by depth effect
この実験の初速と終速の差は, ボールが 2 台のハイスピ ードビデオカメラ設置間隔 $14[\mathrm{~m}]$ 飛翔したときに生じて いる.ピッチャ一後方から撮影した映像からではボールの 投射後からストライクゾーン到達までの時間しか分からな い. そこで, 式（8）に示すように $14[\mathrm{~m}]$ を飛翔したときの 時間を求めた。

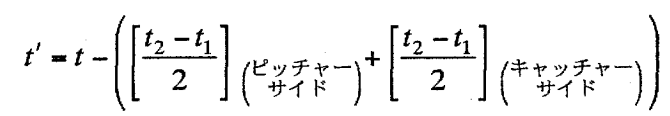

ここで, $t$ 'は $14[\mathrm{~m}]$ を飛翔したときの時間 $[\mathrm{s}], t$ はボールの 投射後からストライクゾーン到達までの時間[s]である.

\section{4-2. 抗力係数 $C_{D}$ の算出方法}

ボールに抗力のみが働いたときの運動方程式は, 式（9） ように表される。

$$
m \frac{d^{2} x}{d t}=-\frac{1}{2} \rho C_{D} A V_{x}^{2}
$$

これを積分すると，

$$
C_{D}=-\frac{2 m}{\rho A t}\left(\frac{1}{V_{x f}}-\frac{1}{V_{x i}}\right)
$$

となる。これより, 初速, 終速, ボールの飛翔時間を実験 により測定することで抗力係数を求めることができる.

\section{4-3. 抗力係数 $C_{D}$ の算出結果}

Table2 に今回実験を行った球種の実験結果の一例を示す.

Fig.13 にジャイロボール, ストレート, フォークの抗力 係数の測定結果を示す.この結果より, ジャイロボールが ストレート，フォークに比べ抗力係数が小さい傾向がある ことが分かる.

Table2 Example of drag coefficient

\begin{tabular}{ccccc}
\hline & $V_{x i}{ }^{\prime}[\mathrm{km} / \mathrm{h}]$ & $V_{x f^{\prime}}[\mathrm{km} / \mathrm{h}]$ & $t^{\prime}[\mathrm{s}]$ & $C_{D}$ \\
\hline 2seam-Gyro & 97.4 & 91.4 & 0.490 & 0.29 \\
4seam-Gyro & 97.5 & 90.8 & 0.496 & 0.32 \\
2seam-Fast & 98.9 & 91.4 & 0.489 & 0.36 \\
4seam-Fast & 98.7 & 91.8 & 0.485 & 0.33 \\
Forkball & 97.1 & 87.9 & 0.516 & 0.44 \\
\hline
\end{tabular}

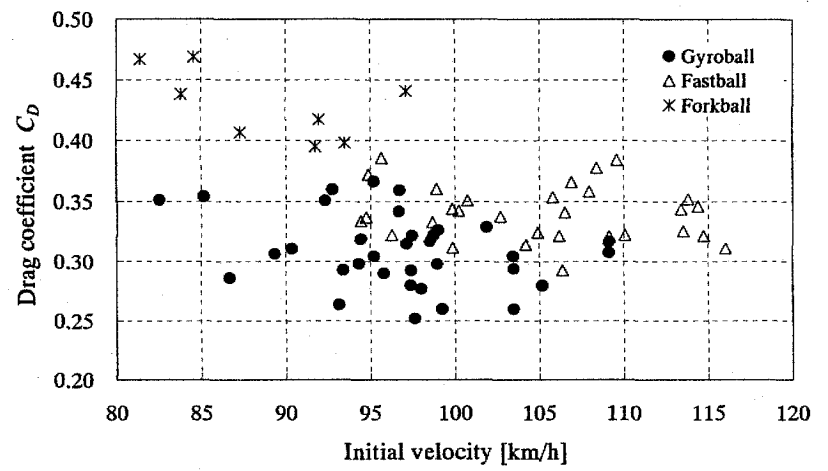

Fig.13 Drag coefficient 
次に, Fig.14にジャイロボールの 2 シームと 4 シームを 区別した測定結果を，Fig.15 にストレートの 2 シームと 4 シームを区別した測定結果を示す. ジャイロボールでは, 2 シームが 4 シームに比べ抗力係数は小さく, ストレートで は, 2 シームが 4 シームに比べ抗力係数は大きくなった. これは, ジャイロボールでは, 4 シームが左右対象の縫い 目位置で回転しながら飛翔するのに対して，2 シームは左 右非対称の縫い目位置で回転しながら飛翔するため, 2 シ 一ムは 4 シームに比べ，ボール周りの流れが不規則的とな り, 後流が乱れ, はく離点が後方になり, 抗力係数が小さ くなったのではないかと考えられる. ストレートでは，2 シームが左右対象の縫い目位置で回転しながら飛翔するの に対して，4 シームは左右非対称の縫い目位置で回転しな がら飛翔するため, ジャイロボールと同様に 4 シームは 2 シームに比べ, 抗力係数が小さくなったのではないかと考 えられる。

それぞれの球種において平均値をとった結果を Table3に 示す。この結果は, ジャイロボールに関しては溝田らの風 洞実験結果 ${ }^{3)}$ とほぼ一致しており，ストレートに関しても 既知の值とほぼ一致している。

\begin{tabular}{cc} 
Table3 & Average of drag coefficient \\
\hline 2seam-Gyro & 0.29 \\
4seam-Gyro & 0.33 \\
2seam-Fast & 0.36 \\
4seam-Fast & 0.33 \\
Forkball & 0.43 \\
\hline
\end{tabular}

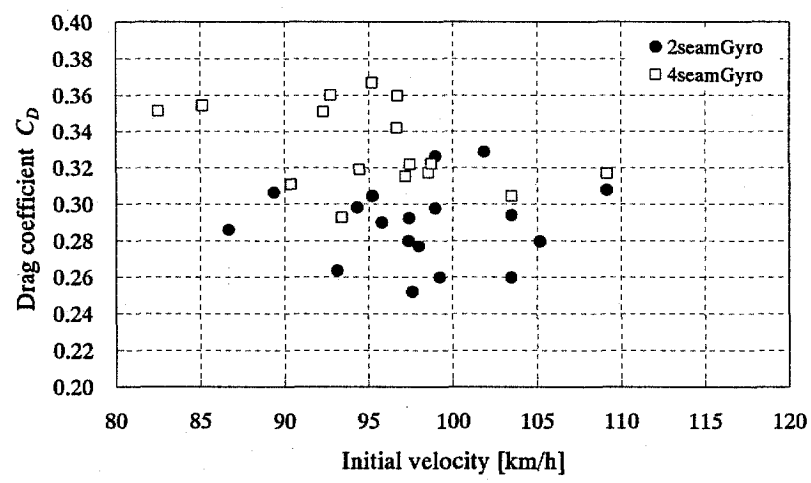

Fig.14 Drag coefficient (Gyroball)

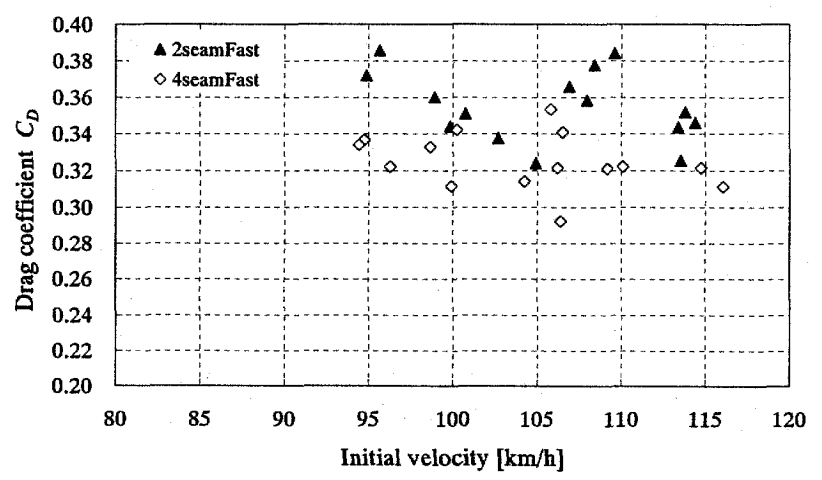

Fig.15 Drag coefficient (Fastball)

\section{5. 結論}

本稿では, ジャイロボールの縫い目位直による空力特性 の相違を確かめるために，野球ボールを害際に投じ，八イ スピードビデオカメラを用いて，軌道及び初速と終速を測 定する実験を行った．比較のためにジャイロボールと同じ 鉿直面内で変化するストレート, フォークについても実験 を行った. その結果以下のことが得られた.

軌道を測定した実験から，揚力が働かないジャイロボー ルが，ストレートとこの実験でのフォークに比べ，大きく 落ちる軌道を描くことが分かった．ストレートとの落差の 差は球速 $100[\mathrm{~km} / \mathrm{h}]$ で約 $20[\mathrm{~cm}]$ であった.しかし, 2 シーム ジャイロと 4 シームジャイロの軌道の差は, ほとんど見ら れなかった. また, 飛翔中の野球ボールの運動方程式と既 知の空力係数を基に数値計算した結果も同様に軌道の差は ほとんど見られなかった。このことから，ジャイロボール の縫い目位置の影響を軌道から捉えることは難しいことが 分かった.

初速と終速を測定し抗力係数を算出した実験から, ジヤ イロボールがストレート，フォークに比べ抗力係数が小さ いことが分かった，さらに，ジャイロボール，ストレート 共に縫い目位置の違いで抗力係数が異なることが分かった 実験結果を平均すると, ジャイロボールでは, 2 シームが $0.29,4$ シームが 0.33 となり, 2 シームが 4 シームに比べ 抗力係数が小さくなった. これは溝田らの風洞実験結果と ほぼ一致した。ストレートでは，2 シームが 0.36, 4 シー ムが 0.33 となり, 4 シームが 2 シームに比べ抗力係数が小 さくなった.

\section{【謝辞】}

本研究の実投球にご協力していただいた九州工業大学生 命体工学研究科の藤井健太郎君, 九州工業大学工学研究科 の比良拓郎君，柜木賢一君に深く感謝致します。

\section{【参考文献】}

1）手塚一志, 姫野龍太郎 : 魔球の正体, ベースボールマガ ジン社 (2001)

2）姫野龍太郎：野球がおもしろくなる変化球の大研究, 岩 波書店, (2002)

3）溝田武人, 小西弘明, 錦織大介 : 硬式野球ボールの変化 球に関する研究(縦スライダーの空気力測定と飛翔軌道 解析), 日本機械学会講演論文集 No.038-1（2003）

4）谷口哲也, 宮崇武, 清水鉄也, 姫野龍太郎 : 硬式野球ボ 一ルに働く空気力の测定，ながれ 25, p257-264（2006）

5）清水鉄也, 姫野龍太郎, 谷口哲也, 桶田史朗, 宮峷武 : 野球ボールにかかる空気力の測定,日本風工学会誌 (2004)

6）姬野龍太郎: 野球の変化球とながれ,ながれ 20,p430-434 (2001)

7) LEROY WARD ALAWAYS and MONT HUBBARD : Experimental determination of baseball spin and lift, Journal of Sports Sciences 19, p349-358（2001） 